\title{
Diagnosis of Entrepreneurial Spirits among Restaurateurs in Malaysia: An Empirical Evidence Using Structural Equation Modelling
}

\author{
Mazalan Mifli \\ Mat Salleh Ayub
}

\begin{abstract}
Managing product innovations that hold future success in today's competitive and dynamic global markets reflects on the firm's domains of entrepreneurship man oeuvres. This research diagnoses the entrepreneurial spirits of restaurateurs in Malaysia by examining their entrepreneurial orientations (EOs) when engaging into new product innovation. The results of the Exploratory Factor Analysis (EFA) indicated that 'the spirit of risk-taking'- one of the nine-domain of EOs that were based upon in this study (Salavou \& Lioukas, 2003) appeared to be unfounded. The eight-domain of EOs was then structured into two-dimensional construct model, and subsequently, tested of its model fit indexes using a covariancebased structural equation modelling (AMOS). The implication of these findings is discussed along with the limitations and future direction of this study.
\end{abstract}

Keywords-menu innovation, product innovation, entrepreneurial orientations, structural equation modelling, restaurant, Malaysia

\section{Introduction}

Firms that show high propensity in entrepreneurial spirits in product innovation are generally having the competitive edge in the marketplace by way outpacing their rival competitors [1-2]. Yet, despite of such proposition, it remains unclear in an empirical evidence to substantiate this occurrence relationship. Theoretically, the fundamental assertion of EO is a reflection of the firms' managerial orientations that fall either one or a combination of these domains: proactive, innovative and risk-takers [2-6]. It is a salient decision-making process that is carried out at the first stage of product innovation process called innovation generation [7-11].

Indeed, EO relates to the firm's managerial orientations that pursuit beyond industrial benchmarking. Such managerial orientation, in fact, is not knew to organizational theory. It first appears in Schumpeter's [1213] earlier research works, which differentiated entrepreneurs from others by having divine individual characteristics and personality traits. Since then, over the years, EO has been a subject of cultural-related traits of entrepreneurs that are strongly correlated to entrepreneurial spirits [14-15]. Such revolutions then transformed EO from an individual's endeavor into a managerial orientation in term of navigating the firm's strategic postures away from dormant methods, practices and decision-making styles [2].

Mazalan Mifli

Mat Salleh Ayub

Universiti Malaysia Sabah

Malaysia
Notably, apart from being innovative, the act of risktaking is highly correlated to entrepreneurial spirits. Such an act refers to those managers (or owners who run the operations) that are bold enough in their decision-making process to enter unchartered territory in relation to the firm's innovation undertakings [16]. Such boldness, however, may not always be radically innovation oriented. Radical innovation is defined as incorporation of new knowledge into the innovation development [17]. This is because innovation that is considered new and bold to the firm may not necessary new in the market, yet it can still be effectual if it is engaged in product-market innovativeness and introduced at the early stage of its life cycle in the marketplace [18-21]. Therefore, continuous improvement of existing innovation works is what needed so that existing service or products can be incrementally improved.

Additionally, proactiveness, on the other hand, refers to "the will and foresight [of the manager] to seize new opportunities" [22: 147]. Specifically, it refers to managerial 'know-how' in seeking new opportunities that hold future needs by way of being a pioneer either in the industry or market [23]. In contrary, innovativeness, according to Lumpkin and Dess [22:142], "reflects a firm's tendency to engage in and support new ideas, novelty, experimentation, and creative process that may result in new product, services or technological process".

\section{Background and Purpose}

Over the years, many consumers' foodservice markets across the globe have reached to a level of saturation point [24-26]. By definition, market saturation refers to a diffusion of similar product orientations in an abundance manner in a given marketplace [19] [27-29]. Due to the nature of entry into a foodservice business is virtually no barrier, though tricky, emergence of new comers offering product concepts that mimicked with those existing ones is archetypal in this industry [29]. This phenomenon, which Jones and Wan [29] called the 'copy-cat system' in one of their four types of product innovation in the foodservice industry, further escalates the degree of the market saturation, and if there is no sudden growth of market demands in the marketplace, depletion of market share gains is inevitable [18]. Hence, such a condition presents great challenges for restaurant entrepreneurs to stay afloat in business and maintain market shares.

Strategically, one of the keys to keep up the business afloat is through innovation, and if such innovation is orchestrated in innovativeness manners, gaining larger market shares is attainable [30-32]. Such a notion is well documented in entrepreneurship paradigm that entails a firm's strategic product innovation maneuver that adopts 
entrepreneurial orientations (EO), such as being proactiveness and willingness to take higher risks, is generally to be more successful [33]. Indeed, the concept of an entrepreneurial orientation (EO) is the reflection a firm's strategic managerial orientations adoption [3]. Yet, strategy in managing product innovation that holds future success or failure in the marketplace also reflects on the firm's levels of innovativeness undertakings [32] [34-37], which then spur the outcome of the types of product innovation [38]. Review in the literature indicates that majority of new products are being developed base on incremental innovation orientations as opposed to the opposite orientations that personify EO [39-42], despite claimed by others of its competitive advantage [2] [43-44].

In the perspective of restaurant industry, two opposing schools of thoughts in regards to menu innovation have been constantly debated. One takes the view that developing and introducing new menu products reflects on the proactiveness of the chef's innovativeness in crafting gastronomic and culinary inventions, whereas on the other side of the coin suggests that foods should be developed based on consumer habits, acceptances and preferences [26]. This paper, however, does not attempt to approve or to disapprove between these two opposing propositions. Instead, over the years, many propositions have been put forward on this subject matter and such debates appear to be endless. In Berthon, Hulbert and Pitt's findings [45], they conclude that product innovation is indeed can create new market and customer. Another study also postulates innovativeness in product innovation by ways of "learning and tracking customer needs, develop new products and services that address those needs, and finally, develop and implement the internal processes that enhance customer-need understanding and product development" [46]. Narver et al. [46] suggest that "a market orientation, whether responsive or proactive, should be the foundation for a business's innovation efforts". Salavou and Lioukas [43] assert that existing approaches to product innovation however are conceptual in nature and lack of empirical evidence. To compete, most firms, if not all, face greater competitions within the industry due to constantly and globally redefined, and therefore, become a subject of investigation across various empirical settings [43] [47] [38-40].

This study, therefore, was set forth to extend EO research, focusing specifically to the restaurant industry in Malaysia. The study's unit of analysis of restaurant sectors was chosen because of the phenomenal growth rate of the industry since the early 2000 that saw an average growth rate percentage of nearly reaching $7 \%$ annually for the past ten years. Out of the six sectors, four of the notable restaurant sectors, namely Full-Service Restaurants (FSR), Fast food, Cafés \& Bars, Street stalls/Kiosks have shown remarkable growth rate where the Cafés \& Bars' sector being the frontrunner follows by FRS and Fast Food with $27 \%, 19 \%$ and $11 \%$ growth rate by number of units [27]. Hence, given the fact that the nature of entry to restaurant business is virtually no barriers [48], the number of units is expected to increase proportionately across the consumer foodservice markets in Malaysia. Though this indispensable growth rate is seen prosperous for the industry, pragmatically, such a market condition is in fact hazardous for business longevity due to progressive depletion of market share as new comers allure to join the fray. Consequently, if there are no sudden new demands, this overly supply of food products and services in the marketplace is potentially detrimental to business sales, and, given the fact that restaurant business has high fatality rate, this could very well lead to many restaurants fall to bankruptcy. To this notion, we posit that for entrepreneurs to have an edge in this competitive saturated market and remain afloat in business, strategically, acute innovation management has to be adhered to in order to potentially create new market and customers [45]. Thus, entrepreneurs that are competing in a saturated consumer market ought to be innovative in their new product development (NPD) and services as this deems to be the key business strategy that they can be relied upon to drive sales growth and gain market shares [24].

Generally, managing new product innovation falls into two domains of orientations that are either to adopt radical or incremental approaches to product innovation [38]. Radical innovation orientations are frequently linked to the concept of EO in both marketing and innovation management literature [36] [43] [49-50]. While most entrepreneurial studies have discreetly conceptualized EO as an act of entrepreneurship domains, a closer review in literature indicates that some firms do practices divergent EOs, which means firms' EOs, can also be in defensive mode [34]. Ansoff [51] argues that the stability, assertiveness and coherence of a strategy within a firm, largely, rely on their management's strategic orientations that subsequently lead to the directional manoeuvre of the firm. Therefore, according to Wood and Robertson [4], the conceptualization of strategic management orientation also includes a range of dormant characteristics of the manager preferences towards "risk-taking, entrepreneurship, objectively, assertiveness and information use". In organizational theory, firms are scale-down based on how well its strategies are being developed, such as those that are guided by well-developed strategies that are "enduring in nature and are aggressively pursed" [35]. While the other side of the scale are those firms with less developed strategies, which are "more influenced by management intuition, hunches and unplanned reactions to unanticipated events" [4]. Both sides of these scales of strategic orientations are terms as "proactive" and "reactive" that designate manager's traits, which in turn influence one firm's managerial behavior [52].

\section{Hypotheses}

Based on the above contextual explanations, a research question is then forwarded as to what EO strategy-decision making might be expected to occur when restaurateurs develop/introduce their menu products in a consumer market that has reached to its pinnacle. As discussed earlier, the spectrum of EO may not always be skewed to offensive approach as propaganda in literature since some entrepreneurs may opt for defensive stands. Strategically, this could be due to the nature of the surrounding business landscapes, such as opportunities and threats, and along with the capability of the management team's strengths and weaknesses. This notion of EO strategy points to managerial challenges in generating ideas and manoeuvring the innovation activities, conditional to the degrees of both external and internal factors being absorbed by the management team. Such a scenario implies that entrepreneurs that are categorized as being defensive are 
likely to rely on incremental approach where existing knowledge is preserved with minimal alterations/medications being put forward to the NPD. On the opposite side, novelty entrepreneurs, in theory, are risktakers and seek new knowledge and incorporated into the NPD so that new products emerged away from the old ones. This suggests the followings:

H1: Restaurateurs when engaging into new product innovation use offensive EO.

$H 2$ : Restaurateurs when engaging into new product innovation use defensive EO.

\section{Iv. Methodology}

This study was conducted via online during the thirdquarter of 2015 using a purposive sampling technique where restaurant establishments were identified from two data bases, namely the Small Medium Enterprises (SME Corp.) and Malaysian Malay Business Chember (Dewan Perniagaan Melayu Malaysia - DPMM). At the time of the online survey being distributed via e-mails, there were nearly four thousand registered and active restaurant establishments. These active members were then identified, and subsequently invited to participate in this study's online survey via their respective valid e-mail addresses. After two weeks of the online survey was e-mailed, two waves of follow-up e-mails were deployed with a simple note of gentle reminder. In early 2016, a total of 357 data received for an estimated response rate of $9.9 \%$. The conventional data cleaning was then performed to this data using SPSS Ver. 22 where minimal cases of data were found to have extreme missing values and they were omitted subsequently. Actual 337 data were reached to be the final sample size of this study and deemed appropriate for further statistical testing. A summary of the respondents' demographic profile is presented in Table 1.

\begin{tabular}{lcc}
\multicolumn{3}{c}{ TABLE. 1. DEMOGRAPHIC PROFILE OF RESPONDENTS N=337 } \\
\hline Variable & Frequency & \% \\
\hline Age & 4 & 1.2 \\
Up to 25 years & 161 & 47.8 \\
26-35 years & 155 & 46.0 \\
36-45 years & 17 & 5.0 \\
46-55 years & & \\
Education & 8 & 2.4 \\
Secondary & 21 & 6.2 \\
Vocational & 131 & 38.9 \\
Diploma & 151 & 44.8 \\
Degree & 26 & 7.7 \\
Postgrad & & \\
Business tenure & 54 & 16.0 \\
1-3 years & 147 & 43.6 \\
4-6 years & 126 & 37.4 \\
7-10 years & 10 & 3.0 \\
>10 years & & \\
Types of Business & 74 & 22.0 \\
Sole proprietor & 151 & 44.8 \\
Partnership (other than family) & 44 & 13.1 \\
Family partnership & 48 & 14.2 \\
Company (other than family) & 20 & 5.9 \\
Family company & & \\
Franchise & 149 & 44.2 \\
Yes & 188 & 55.8 \\
No & & \\
Types of restaurant & 131 & 38.9 \\
Cafes/bars & 10 & 3.0 \\
Street stalls/kiosk & 47 & 13.9 \\
Fast food & 149 & 44.2 \\
Full service restaurant (FSR) & & \\
\hline &
\end{tabular}

The scale measure used in this study to diagnose restaurant entrepreneurs' EO was adopted from the nine original measurement scale of Salavou and Lioukas' [43] EO by-polar semantic differential seven-point scale. This research instrument scale was deemed appropriated and had been previously used to measure product innovation orientations [38], where the characteristics of both incremental (defensive) and radical (offensive) orientations were paired side-by-side using a seven-point scale.

\section{v. Findings and Discussions}

To meet the aimed of this study's main objective, an exploratory factor analysis (EFA) was first performed to seek the factorial structure of both EO spectrum. In the EFA, we specifically set the extraction factors to two as it was already known there are only two dimensions of innovation orientation: incremental (defensive) and radical (offensive), deploying extraction method of Maximum Likelihood Estimation (MLE). The results of the EFA appeared to support confirmed of the two factors, which is summarized in Table 2 along with its psychometric parameter values.

TABLE. 2. EXPLORATORY FACTOR ANALYSIS (EFA)

\begin{tabular}{lcc}
\hline Construct: Entrepreneurial Orientation (EO) & \multicolumn{2}{c}{ Pattern } \\
(Coefficient Alpha for scale:0.852 ) & F1 & F2 \\
\hline & & \\
Factor 1: Incremental & .758 & \\
EO1-Product introduction & .501 & \\
EO2-Changes of products & .744 & \\
EO7-Strategic respond to action & .931 & \\
EO8-Strategy for new product introduction & .693 & \\
EO9-Strategy for competitive actions & & .897 \\
Factor 2: Radical & & .942 \\
EO3-Emphasis of product development & & .608 \\
EO5-Innovative strategy acts & & \\
EO6-Innovative strategy adoptions & 50.16 & 13.55 \\
& 50.16 & 63.72 \\
\% of total variance explained & .833 & .730 \\
Cumulative variance (\%) & 5 & 3 \\
Coefficient alpha & & \\
Number of items & & \\
\hline Extraction method: Maximum Likelihood Estimation (MLE) & \\
Rotation Method: Promax with Kaiser Normalization & & \\
anotation converged in 3 iterations &
\end{tabular}

Subsequently, the second-order latent variable model of EO was examined of its validity and reliability along with its model fit indexes using AMOS Ver. 22; a co-variance based structural equation modelling. Summary of its findings are presented in Table 3. Assessment between the AVE values and the squared correlations among the latent variables was also made to measure the model dimensional discriminant validity and proved satisfactory where each of the latent variables was found related to its only own measures than with other.

TABLE. 3. PSYCHOMETRIC PROPERTIES OF THE OUTER MODELS

\begin{tabular}{lcccccc}
\hline $\begin{array}{l}\text { Latent } \\
\text { variables }\end{array}$ & Items & Loadings & SE & Cr & CR & AVE \\
\hline Incremental & EO1 & .795 & .112 & $11.190^{*}$ & .871 & .628 \\
& EO2 & .729 & .112 & $12.834^{*}$ & & \\
& EO8 & .886 & .098 & $15.137^{*}$ & & \\
Radical & EO9 & .752 & .072 & $11.190^{*}$ & & \\
& EO3 & .713 & .125 & $10.008^{*}$ & .580 & .733 \\
& EO6 & .807 & .080 & $10.080^{*}$ & & \\
\hline
\end{tabular}

Note: SE: standard error; Cr: critical ratio; CR: composite reliability; AVE: average variance extracted. Item labelled EO7 and EO5 were omitted from the structural model due to lower loading values $>0.7$. $* \rho<0.01$ 
Proc. of The Fifth Intl. Conf. On Advances In Economics, Social Science and Human Behaviour Study - ESSHBS 2016 Copyright (C) Institute of Research Engineers and Doctors, USA .All rights reserved.

ISBN: 978-1-63248-107-8 doi: 10.15224/ 978-1-63248-107-8-45

Results of the Confirmatory Factor Analysis (CFA) yielded empirically acceptable model fit indexes as all the required values were found above the threshold values with a $\rho$ value of .055 obtained: a chi-square to $\mathrm{df}$ ratio $\left(\chi^{2} / \mathrm{df}\right)$ of 2.054 , root mean square error of approximation (RMSEA) of .056, Tucker-Lewis index (TLI) of .983, comparative fir index (CFI) of .993, goodness of fit index (GFI) of .988, Bentler-Bonet (1980) normed fit index (NFI) of .987, and standardized root mean square residual (SRMR) of .0242.

\section{Result of Confirmatory Factor Analysis (CFA)}

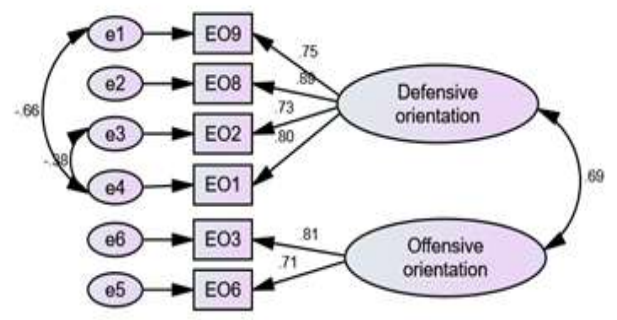

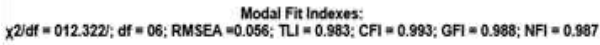

The findings point that the model of EO yielded in this study indicates that restaurateurs appeared not truly embrace the domains of radical EO when engaged into new product development. The result of the CFA clearly shows that retained item labelled EO1, EO2, EO8 \& EO9 that are significant at $\rho<0.01$ can be reasonably confirmed that restaurateurs in Malaysia are practicing incremental product orientations. Despite of the prevailing consumer foodservice market condition in major cities like Kuala Lumpur, Penang and Johor Bahru have reached to its saturation point [54], and many more territorial cities predicted to follow suit, the result can also be interpreted that the consumer foodservice markets in Malaysia in general are less likely to have product newness. This is because of all the nine-item measures of EO, only item labelled EO3 \& EO6 found confirmed support of radical product orientation adopted by Malaysian restaurateurs.

\section{Acknowledgment}

We would like express our appreciation to SME Corp and Dewan Perniagaan Melayu Malaysia, Sabah for sharing information with us during the course of this research. We are also immensely grateful to our faculty members for their comments and guidance throughout this research work that greatly assisted the research.

\section{References}

[1] G. Avlonitis, H. Salavou. Entrepreneurial orientation of SMEs, product innovativeness and performance. Journal of Business Research, 60(5) (2007) 566 - 575

[2] S.K. Wong. Impacts of environmental turbulence on entrepreneurial orientation and new product success. European Journal of Innovation Management, 17(2) (2014) 229-249

[3] D. Miller. The correlates of entrepreneurship in three types of firms. Management Science, 29(7) (1983) 770-791
[4] V. R. Wood, K. R. Robertson. Strategic orientation and export success: an empirical study. International Marketing Review, 14(6) (1997) 424 - 444

[5] D. Kandemir, N. Acur. Examining proactive strategic decisionmaking flexibility in new product development. Journal of Product Innovation Management, 29(4) (2012) 608-622

[6] K. Talke, E.J. Hultink. The Impact of the Corporate Mind-set on New Product Launch Strategy and Market Performance. Journal of Product Innovation Management, 27(2) (2010) 220-237

[7] J.M. Utterback. The process of technological innovation within the firm. Academy of Management Journal, March (1971) 75-88.

[8] J.L. Pierce, A.L. Delbecq. Organization Structure, Individual Attitudes and Innovation. Academy of Management Review, 2(1) (1977) 27-37

[9] K.E. Knight. A descriptive model of the intra-firm innovation process. The Journal of Business, 40(4) (1967) 478-496.

[10] R.T. Frambach, N. Schillewaert. Organizational innovation adoption: a multi-level framework of determinants and opportunities for future research. Journal of Business Research, 55 (2002) 163-176

[11] M. Mifli. H. Rahmat \& A. Zainal. Managing menu innovation in a saturated market: an empirical evidence from the chain restaurants in Malaysia. Tourism and Hospitality Research, (2015) DOI: $10.1177 / 1467358415614347$

[12] J.A. Schumpeter. The theory of economic development. Cambridge, MA: Harvard University Press (1934)

[13] J.A. Schumpeter. Capitalism, Socialism, and Democracy. New York: Harper and Brothers (1942)

[14] W.B. Gartner. Who is an entrepreneur? is the wrong question. American Journal of Small Business, I (Spring) (1988) 11-32.

[15] K.G. Shaver, L.R. Scott. Person, process, choice: The psychology of new venture creation. Entrepreneurship Theory and Practice, (1991) 23-45.

[16] D. Miller, P.H. Friesen. Archetypes of Strategy Formulation. Management Science, 24(9) (1978) 921-933

[17] M. L. Tushman, P. Anderson. Technological discontinuities and organizational environments. Administrative Science Quarterly, 31 (1986) 439-65

[18] K. Hashimoto. Product Life Cycle Theory: A Quantitative Application for Casino Courses in Higher Education. International Journal of Hospitality Management, (22) (2003) 177- 195

[19] J. Cobbenhagen. Successful innovation: towards a new theory for the management of SMEs, Edward Elgar: Cheltenham (2000)

[20] M. Hughes, P. Morgan. Exploitative Learning and Entrepreneurial Orientation Alignment in Emerging Young Firms: Implications for Market and Response Performance. British Journal of Management, 18(4) (2007) 359-375

[21] M.L. Lindgren, G.C. O'Connor. The Role of Future-Market Focus in the Early Stages of NPD across Varying Levels of Innovativeness. Journal of Product Innovation Management, 28 (5) (2011) 787-800

[22] G.T. Lumpkin, G. Dess. Clarifying the entrepreneurial orientation construct and linking it to performance. Academy of Management Review, 21 (1996) 135-172

[23] A. Rauch, J. Wiklund, G.T. Lumpkin, M. Frese. Entrepreneurial Orientation and Business Performance: An Assessment of Past Research and Suggestions for the Future. Entrepreneurship Theory and Practice, 33(3) (2009) 761-787

[24] T. Feltenstein. New-product development in food service: a structured approach. Cornell Hotel and Restaurant Administration Quarterly, 27(3) (1986) 63-71

[25] P. Jones. Managing hospitality innovation. Cornell Hotel and Restaurant Administration Quarterly, 37(5) (1996) 86

[26] M. Mifli. A simultaneous assessment of the hierarchical models of market orientation and external environmental factors (EEFS) on the relationship between innovation orientation and concept development in chain restaurants, Ph.D. Thesis, University of Technology MARA University of Technology MARA (2014)

[27] P. Drucker. Managing in a time of Great Change. New York : Truman Talley/E.P. Dutton (1995)

[28] M.E. Porter, C.V.D. Linde. Green and Competitive: Breaking the Stalemate. Harvard Business Review, September-October 1995. 
[29] P. Jones, L. Wan. Innovation in the UK Food-service Industry. International Journal of Contemporary Hospitality Management, 4(4) (1992) 1-6

[30] G. G. Dess, G.T. Lumpkin, J.G. Covin. Entrepreneurial strategy making and firm performance: tests of contingency and configurational models. Strategic Management Journal, 18(9) (1997) 677-695

[31] D.W. Lyon, G.T. Lumpkin, G.G. Dess. Enhancing entrepreneurial orientation research: operationalizing and measuring a key strategic decision making process. Journal Manage, 26(5) (2000) 1055-85

[32] K. Atuahene-Gima, A. Ko. An Empirical Investigation of the Effect of Market Orientation and Entrepreneurship Orientation Alignment on Product Innovation. Organization Science, 12(1) (2001) 54-74

[33] D.F. Jennings, J.L. Lumpkin. Insights into the Relationship between Strategic Momentum and Environmental Scanning: An Empirical Analysis. Akron Business and Economic Review, 20 (1) (1989) 8493

[34] J.G. Covin, D. Slevin, M. Heeley. Pioneers and followers: competitive tactics, environment, and firm growth. Journal of Business Venturing, 15(2) (1999) 175-210

[35] R.E. Miles, C. Snow. Organizational Strategy, Structure, and Process. New York: McGraw-Hill (1978)

[36] D. Miller, P. Friesen. Innovation in Conservative and Entrepreneurial Firms: Two Models of Strategic Momentum. Strategic Management Journal, 3 (1982) 1-25

[37] H. Mintzberg. The Nature of Managerial Work. New York: Harper \& Row (1973)

[38] W.J. Abernathy, K.B. Clark. Innovation: Mapping the winds of creative destruction. Research Policy, 14(1) (1985) 3-22

[39] Booz, Allen, Hamilton. New product management for the 1980s, New York: Booz, Allen and Hamilton Inc. (1982)

[40] N.D.J. Hanna, R.E. Ayers, R.G.L. Gordon. New product development practices in consumer versus business products organizations. Journal of Product \& Brand management, 4(1) (1995) $33-55$

[41] W.G. Fuller. New food product development from concept to the market place. Boca Rotan: CRC Press (1994)

[42] S.G. Dacko. Benchmarking competitive responses to pioneering new product introductions, Benchmarking: An International Journal, 7(5) (2000) $324-342$

[43] H. Salavou, S. Lioukas. Radical Product Innovations in SMEs: The Dominance of Entrepreneurial Orientation. Creativity and Innovation Management, 12(2) (2003) $94-108$

[44] S.D. Saleh, C.K. Wang. The Management of Innovation: Strategy, Structure, and Organizational Climate. IEEE Transactions on Engineering Management, 40(1) (1993) 14-21

[45] P. Berthon, J.M. Hulbert, L. Pitt. Innovation or customer orientation? An empirical investigation. European Journal of Marketing, 38(9/10) (2004) 1065 - 1090

[46] J.C. Narver, F. Stanley, S.F. Slater, D.L. MacLachlan. Responsive and Proactive Market Orientation and New-Product Success. Journal of Product Innovation Management, 21(5) (2004) 334-347

[47] A. Pérez-Luño, J. Wiklund, R.V. Cabrera. The dual nature of innovative activity: How entrepreneurial orientation influences innovation generation and adoption. Journal of Business Venturing, 26(5) (2011) 555-571

[48] B. Davis, A. Lockwood, P. Alcott, I. Pantelidis. Food and Beverage Management. 5th ed. New York, NY: Routledge (2000)

[49] K.Z.Z. Zhou, C.K. Yim, D.K. Tse. The Effects of Strategic Orientations on Technology-and Market-Based Breakthrough Innovations. Journal of Marketing, 69(2) (2005) 42-60.

[50] G. Hame, C.K. Prahalad. Competing for the future. Boston: Harvard Business. School Press; 1994.

[51] I. Ansoff. Corporate strategy, McGraw Hill, New York, 1965

[52] M.E. Porter. Competitive Strategy: Techniques for Analyzing Industries and Competitors. New York: Free Press, 1980

[53] P.M. Bentler, D.C. Bonnet. Significance Tests and Goodness of Fit in the Analysis of Covariance Structures. Psychological Bulletin, 88(3) (1980) 588-606

[54] Euromonitor International. Consumer food service industry in Malaysia (2012)
About Author (s)

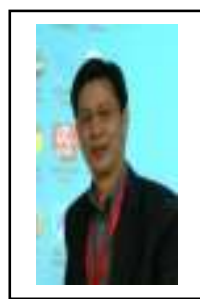

Mazalan Mifli, PhD. is a Senior Lecturer in the Department of Hotel Management,

Faculty of Business, Economics and Accountancy at the Universiti Malaysia Sabah. He has a wide variety of experience in the hospitality industry and has worked in both locally and internationally. Some of his publications appeared Tourism and Hospitality

Research (THR) and Advanced Science Letters. His main research interests are in Product innovation in food service industry.

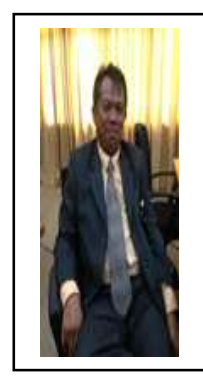

Mat Salleh B Ayub is a Senior Lecturer in the Department of Entrepreneurship, Faculty of Business, Economics and Accountancy at Universiti Malaysia Sabah. He has vast experience in the area of entrepreneurship and his main research fields encompass entrepreneurship, small and medium enterprises and business performance. 